\section{Generell kirurgi på hjemmekino}

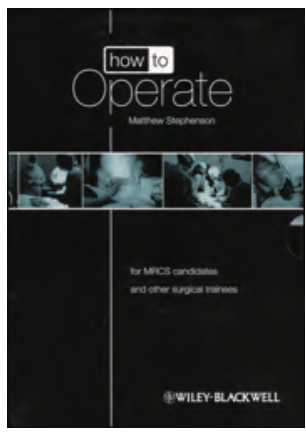

\section{Matthew Stephenson}

\section{How to operate}

For MRCS candidates and other surgical trainees. 3 DVD, 288 s, ill. Chichester:

Wiley-Blackwell, 2012. Pris GBP 75

ISBN 978-0-470-65744-7

Denne boksen, bestående av tre DVD-filmer og en instruksjonsbok, er ment for utdanningskandidater i generell kirurgi, og målgruppen er primært eksamenskandidater til den britiske MRCS (Membership Examination of the Royal College of Surgeons).

Rundt 40 av de mest vanlige kirurgiske prosedyrene innen generell kirurgi, inkludert noen urologiske prosedyrer, øre-nese-hals-prosedyrer (tyreoidektomi og trakeostomi) og et par ortopediske prosedyrer, blir presentert i filmene. Noen av disse er ikke lenger aktuelle for det norske pensumet, men kan være nyttige å se allikevel. Totalt sett er det ti timer med film som er laget som instruksjonssnutter, varierende fra noen minutter til opp mot en liten halvtime.

Innen generell kirurgi omtales ulike brokkinngrep, abscessdrenasjer, appendektomi og tilgang til abdomen (både laparoskopisk og åpent). Av karkirurgiske prosedyrer tas det med samtlige som er gjeldende for generell kirurgi, i tillegg til enkelte b-grenist-inngrep, men ingenting om endovaskulær behandling. Innen urologi omtales skrotalinngrep, nefrektomi (åpen) og mindre inngrep som vasektomier og omskjæringer, men ingen perkutane eller transuretrale inn-

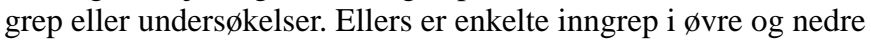
gastrointestinaltraktus tatt med (gastrektomi, splenektomi og åpen kolecystektomi for $\varnothing v r e, o g$ høyresidig åpen kolektomi for nedre), inkludert noen anastomoser og stomier, samt torakotomi (tilgang), men ikke lever-, pancreas- eller rektumkirurgi. I et eget appendiks er det kapitler med filmsnutter av kirurgiske instrumenter, suturmaterialer (typer og valg), Verdens helseorganisasjons (WHO) sjekkliste for trygg kirurgi, pasientsikkerhet og noe om samtykke og basisferdigheter i kirurgi.

I det hele er inntrykket godt og interessant. De fleste filmene er konsise og poengterte og redigert slik at man ikke «sovner» $i$ en lang seanse. I den lille boken som har samme størrelse som et DVD-deksel, er det et tilsvarende kapittel for hver filmsnutt. Der er hver prosedyre oppsummert i en boks med kjernepunkter og fet skrift for nøkkelord.

Fremførelsen er i det hele på det jevne, selv om man merker at det ikke står et profesjonelt og erfarent filmteam bak produksjonen. I flere av filmene er det forstyrrende elementer, som uønsket bakgrunnslyd (andre som prater under opptak, eller musikk som står på), eller folk som går frem og tilbake i bakgrunnen (spesielt i de seansene hvor kirurgen forteller om inngrepet før prosedyren dette kunne med fordel vært tatt opp i et studio eller uforstyrret på et bakrom).

Tradisjon og individuelle varianter vil som alltid prege en del av de tekniske løsningene for kirurgien, men det er dog litt overraskende for undertegnede at man instruerer feste av nett ved lyskebrokkirurgi med å sette $6-8$ agraffer i lysken. Å bruke transversalsnitt ved tilgang for høyresidig hemikolektomi er kanskje mer snakk om tradisjon enn evidens, og at det noe «overraskende» viser seg at demonstrasjonskasus har innvekst i bukveggen lateralt, gjør at litt av «standardprinsippet» for prosedyren faller bort. Flere av bildene i den tilhørende boken er for små og gjengitt med dårlige farger/oppløsning slik at instruksjonsverdien faller bort.

Totalt sett er dette en interessant pakke for utdanningskandidater, selv om kun mindre deler av kirurgien dekkes. Filmpakken kan likevel være et supplement til andre kilder med filmmateriale, som www.websurg.com. I flere lærebøker tilbyr man også etter hvert tilleggsmateriale på film, og på YouTube er et økende antall filmer tilgjengelig, dog uten kvalitetssikring.

\section{Kjetil Søreide}

Gastrokirurgisk avdeling

Stavanger universitetssjukehus

\section{Velskrevet om sammenhengen mellom motornevronsykdom og demens}

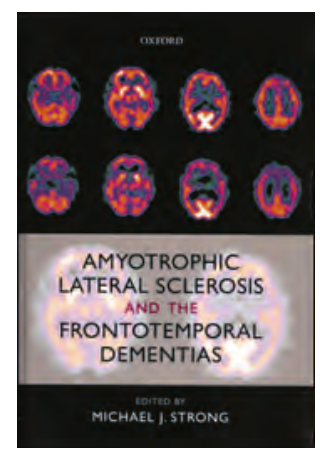

\author{
Michael J. Strong, red. \\ Amyotrophic lateral sclerosis
}

and the frontotemporal dementias

413 s, tab, ill. Oxford: Oxford University Press, 2012. Pris GBP 90

ISBN 978-0-19-959067-4

Som medisinstudent var jeg med på undervisning om amyotrofisk lateral sklerose (ALS) holdt av lord John Walton. Han tok med seg en pasient med langtkommen ALS og beskrev sykdommen som forferdelig vanskelig for både pasient og lege. Han nevnte imidlertid som et lyspunkt at pasienter med ALS beholdt sine kognitive evner. Senere observasjoner har vist at det ikke er tilfelle. Som det fremkommer i denne utgivelsen, kan så mange som $60 \%$ av pasienter med ALS også utvikle kognitive og atferdsmessige forstyrrelser på grunn av frontotemporal affeksjon.

Boken er godt skrevet av eksperter fra hvert av fagfeltene. De starter med en beskrivelse av naturlige varianter av nevrodegenerative sykdommer som ALS og Parkinsons sykdom og demens. Selv om vi ennå ikke vet hva som forårsaker disse sykdommene, belyses sykdomsprosesser som sannsynlig har både genetiske og ervervede faktorer. Forfatterne gir også en utmerket oversikt over motornevron og frontotemporale demenssyndromer fra klinisk arbeid til patologi, og særlig hvordan disse to sykdomsprosessene kan henge sammen. Oversikten dekker den genetiske fremgangen og har med den siste og hyppigste genetiske årsaken, nemlig heksanukleotidrepetisjonen i C9ORF72-genet, dog ikke forskningen som viser hvor hyppig forekomst den har blant pasienter med sporadisk ALS.

Det er flere kapitler om sykdomsmekanismer, og forfatterne beskriver bl.a. en av de siste teoriene om hvordan forstyrret RNAmetabolisme kan spille en rolle i utviklingen av disse sykdommene.

Hovedhensikten er å gi en oppsummering av sammenhengen mellom motornevronsykdom og demens. Dette er ikke en praktisk håndbok for «hverdagsnevrologer». Den er velskrevet og anbefales for dem som $\varnothing$ nsker en grundig teoretisk gjennomgang av feltet.

\section{Laurence Bindoff}

Avdeling for nevrologi

Haukeland universitetssykehus 